\title{
PREDICTING FINANCIAL DISTRESS USING ALTMAN SCORE, GROVER SCORE, SPRINGATE SCORE, ZMIJEWSKI SCORE (CASE STUDY ON CONSUMER GOODS COMPANY)
}

\author{
Hantono $^{1}$ \\ ${ }^{1}$ Accounting Study Program, Universitas Prima Indonesia, Jalan Belanga No.1 Simp.Ayahanda Medan, \\ Sumatera Utara, 20118, Indonesia \\ Corresponding e-mail: hantono_78@yahoo.com
}

\begin{abstract}
This study aims to detect the financial distress on consumer goods companies listing on the Indonesia Stock Exchange 2013-2017 by using altman score, grover score, springate score, zmijewski score.The object of this study is all consumer goods companies listing on the Indonesia Stock Exchange which publishes audited financial statements for fiscal year 2013 2017, which amounted to 24 (twenty four) companies. The sampling technique is by using purposive sampling method where the sample is determined based on certain criteria determined by the researcher and has limitations in terms of generalization. The sample of research is 42 (fourty two companies) Data collection method using documentation method Data analysis technique used is descriptive qualitative analysis using altman score, grover score, springate score, zmijewski score.
\end{abstract}

Keywords: altman score, grover score, springate score, zmijewski score, financial distress JEL Classification: G10, G33

Article info:

Received 8 February 2019

Revised 1 March 2019

Accepted 1 May 2019

Available online 7 May 2019

\section{INTRODUCTION}

Business competition in the globalization era requires every company to improve their performance in order to reach the optimized goal. The development of consumer goods industry can be utilized to view the industrial development nationally. This development can be seen from the aspect of product quality and industrial performance in general. Consumer goods company has experienced development both in developed countries and developing countries, one of which is in Indonesia. With the plentiful advantages of food and beverages industry, new enterprises keep on emerging. If companies are not able to handle the occuring change, the volume of business would decrease which would eventually cause bankruptcy.

Brimantyo et.al (2012) claimed that the need of analysis and prediction of financial condition become highly important, not only towards investors and creditors, but also towards the company itself in order to evaluate corporate performance. This analysis is important to ancitipate bankruptcy in the future. Corporate financial condition would show the level of corporate financial health. Corporate financial health can be known from analyzing the company's financial reports. If a company enters financial distress period and not handled immediately, it would cause bankruptcy. To prevent bankruptcy, various policies, strategies and assistance, both internal and external, is needed. (Fahmi, 2013: 157158). Aziz and Dar (2006) claimed that bankruptcy prediction is an important enhancement for corporate governance. The economic world has become cautious on the risk involved in corporate responsibility, especially after the death of giant companies such as WorldCom and Enron. One of the main objective of Basel II Policy is to minimize credit risks. Various 
models has been utilized to predict corporate bankruptcy. These methods has their own strengths and drawbacks, and choosing among them to an indirect empirical application.

Many literatures make use of financial distress model to predict corporate bankruptcy, however there are still a few researches comparing which is the better financial distress prediction to use. Previous researches has been doing comparisons of model accuracy using several financial distress models, like one conducted by Enny (2014) who, in her research, concluded that the springate model is the best to apply in transportation companies in Indonesia due to the high level of accuracy and low error level comparing to the other models. Reza (2015) in his research, concluded that the best delisting predictor method is the Altman method which has an accuracy level of $71 \%$, followed by springate having an accuracy level not far from Altman, which is $70 \%$, and the last is Zmijewski method having an accuracy level of only 65\%. Meita (2016) concludes that Altman Z-score and Springate model gives a similar level of accuracy in predicting bankruptcy in coal mining company, with the amount of $88,888 \%$, while the Zmijewski model gives a bankruptcy prediction value of $66,666 \%$. Fauzan (2017) in his research concluded that Altman Z-Score model has an accuracy level of 46,67\% with error type of 53,33\%. Springate and Zmijewski model has an error level of $100 \%$, therefore both models are not applicable for banking company. The Grover model has an accuracy level of $100 \%$ and error type of $0 \%$.

Edi and May (2018) who conducted a comparison of financial distress model accuracy, claimed that Altman, Springate, Zmijewski, and Grover model is applicable towards predicting financial distress. The Springate model is the most suitable prediction model for financial distress compare to the other models due to having the highest accuracy level based on coefficient determination testing, which is $69,7 \%$, followed by Grover, Altman, and Zmijewski. Looking at the difference from the above researches, this research reviews the difference of Altman Z-score, Springate, Zmijewski and Grover model in predicting bankruptcy. This research is also conducted to determine the most accurate method in predicting bankruptcy in consumer goods company listed in Indonesia Stock Exchange.

\section{LITERATURE REVIEWS}

Financial Distress. Aghajani and Jouzbarkand, M. (2012), bankruptcy is a situation when a company or a natural person's financial positions low and weak. To the extent that in practice and legal way they are unable to pay their debts and fulfill their obligations. According to Rini (2015: 447), financial distress is a financial condition where the corporate financial condition is unhealthy or in a crisis. Financial distress is a phase of corporate financial decline before either bankruptcy or liquidation. According to Prihadi (2008: 177), bankruptcy is a condition where companies are no longer able to pay off their obligation. Bankruptcy is a condition where a company experiences a financial crisis and no longer able to operate well.

Altman Score. The equation of Z-Score to predict corporate bankruptcy was first published by Edward I. Altman in The United States in 1968, used to predict the possibility of companies going through bankruptcy in two years period. Z-Score model was first introduced by Edward I. Altman in 1968, claiming that companies with low profitability is highly potential towards bankruptcy. The method of measuring Altman Z Score variable is as follows:

$$
\mathrm{Z}=1.2 \mathrm{Z}_{1}+1.4 \mathrm{Z}_{2}+3.3 \mathrm{Z}_{3}+0.6 \mathrm{Z}_{4}+0.999 \mathrm{Z}_{5}
$$

where $Z_{1}$ is working capital divided by total assets, $Z_{2}$ is retained earnings divided by total assets; $Z_{3}$ is earnings before interest and taxes by total assets; $Z_{4}$ is market capitalization by book value of liabilities; $Z_{5}$ is sales by total assets. The criteria of predicting bankruptcy on ZScore model, if $Z<1,8$; it is included in financial distress company, while if $Z$ is between 
1,81 and 2,99; it is included in grey area (in a crisis) company, and if $\mathrm{Z}>2,99$; it is considered a healthy company (Diakomihalis, 2012).

Grover Score. Grover model is a model created by designing and reassessment towards Altman Z-score model. Jeffrey S. Grover uses samples accordingly to Altman Zscore model in 1968 by adding 13 new financial ratio. The samples used are 70 companies, 35 of which experiencing bankruptcy and 35 others do not, between 1982 and 1996. Grover (2001) in Prihanthini (2013) results in an equation as follows:

$$
\mathrm{G}=1,650 \mathrm{X}_{1}+3,404 \mathrm{X}_{2}-0,016 \mathrm{X}_{3}+0,057
$$

where $X_{1}$ is working capital by total assets ; $X_{2}$ is net profit before interest and tax/total assets; $\mathrm{X}_{3}$ is return on assets (ROA). Grover model categorized companies in bankruptcy with the score less than or equal to - $0,02(Z<-0,02)$. While the value for companies categorized as not in bankrupt is $0,01(Z>0,01)$ (Prihanthini \& Sari, 2013).

Springate Score. This model was developed in 1978 by Gorgon L.V. Springate. Springate model is a ratio model using multiple discriminate analysis or MDA to choose 4 out of 19 financial ratio popular in literatures, which are best to differentiate bankrupt and non-bankrupt sound business. Springate model is as follows:

$$
\mathrm{S}=1.03 \mathrm{~A}+3.07 \mathrm{~B}+0.66 \mathrm{C}+0.4 \mathrm{D}
$$

where A is working capital bytotal assets; B is net profit before interest and tax/total assets; C is net before taxes/current liabilities; $D$ is sales by total assets. Criteria for Springate model equation are if $Z<0,862$ then it is categorized as bankrupt company and if $Z>0,862$ then it is categorized as healthy (Rhomadhona, 2014).

Zmijewski Score. Extension of bankruptcy prediction study was conducted by Zmijewski (1983) whom added financial ratio validity as corporate financial failure detection tool. The model successfully developed is as follows:

$$
X=-4,3-4,5 X_{1}+5,7 X_{2}-0,004 X_{3}
$$

where $X_{1}$ is return on assets; $X_{2}$ is debt ratio; $X_{3}$ is current ratio. Zmijewski (1984) claimed that companies are considered in distress if the probability is more than 0 . In another words, the value of $X$ is 0 . Therefore, cut-off value which applies in this model is 0 . This means companies with the $\mathrm{X}$ value more than 0 are predicted with financial distress in the future. However, companies with the $\mathrm{X}$ value below 0 are predicted not to experience financial distress.

Altman Score Towards Financial Distress. NYU Stern Finance Professor Edward Altman, developed the Altman Z-score formula in 1967, and it was published in 1968. In 2012, he released an updated version called the Altman Z-score Plus that one can use to evaluate public and private companies, manufacturing and non manufacturing companies, and U.S. and non-U.S. companies. One can use Altman Z score Plus to evaluate corporate credit risk (https://www.investopedia.com/terms/a/altman.asp). Safitra (2013) in her research showed that there were two companies in a healthy state. For companies indicated as vulnerable, they need to have increase in sales, revenue, operation expense as optimized as possible and pay attention to the equity market value. Kurniawanti (2013) in her research showed that there were three food and beverages company in a healthy state, one company in grey area and one company in a bankruptcy state. Jefri (2016) in his research in 2012 showed that there was one food and beverages company in a bankruptcy state, in 2013 there was one company in a healthy state turned into grey area and 6 companies always in a healthy state from 2012-2014. Kakauhe and Pontoh (2017) conducted a research towards the accuracy of Z-Score method in predicting the bankruptcy of manufacturing company, consumer goods sector where in general companies indicated are in a healthy state due to having increase in sales which causes increase in revenue. Besides that, there was an increase in total assets, both current assets and fixed assets. For companies indicated in the grey area or having potential towards bankruptcy, and companies indicated in bankruptcy due to 
decrease in sales, decrease in corporate assets, retained earnings and earnings before tax and negative interest, plus loss experienced by the company. Based on the explanation, the hypothesis are as follows:

$\mathbf{H}_{1}$. Altman significantly affects financial distress prediction.

Grover Towards Financial Distress. Pambekti et al (2014), their research proved that Grover model can be used in predicting financial distress. Gunawan et al (2017), their research showed that Grover model is able to predict financial distress. This shows that financial ratios used in Grover model are able to illustrate a company's financial distress. Grover model uses three financial ratio to predict financial distress. Fauzan and Sutiono (2017), their research showed that Grover model has an accuracy level of $100 \%$ with error type $0 \%$. Therefore, it can be concluded that Grover model is the best to be applied in go public banking company. Syamni et.al (2018), The bankruptcy prediction models offer different findings of the performances of the coal mining companies in Indonesia over the period 2013-2015. The Grover model found the largest number of companies in the healthy category. Based on the explanation, the hypothesis are as follows:

$\mathbf{H}_{2}$. Grover score has a significant effect in predicting financial distress.

Springate Score Towards Financial Distress. Ben et.al (2015) conducted a research in property and real estate companies, showing that there were eight companies in the category of non-bankrupt potential, nine in potential bankrupt, five in changing categories from bankrupt potential to non-bankrupt potential, five in changing categories from nonbankrupt potential to bankrupt potential. Meiliawati (2016), her research showed that Springate and Altman Z Score model has a significant difference in predicting financial distress potential in cosmetic companies listed in Indonesia Stock Exchange due to the utilization of different ratio in calculating financial crisis level. The next result shows that Springate model is the most accurate model in predicting financial distress potential in cosmetic sector listed in Indonesia Stock Exchange with the accuracy level of 91,66\%, where Altman accuracy level is only $60,41 \%$. This is due to Springate model using Earnings Before Taxes to Current Liabilities (EBTCL) ratio, in which this ratio is considered more dominant in reflecting cosmetic companies listed in Indonesia Stock Exchange. Abadi (2017), his research showed that the calculation result of financial ratio calculated using Springate S-Score between research period 2013-2014, the result showed that there were 19 property companies indicated bankrupt potential. Therefore, it can be concluded that there are property sector companies with a potential of bankruptcy with springate s-score analysis model. Based on the explanation, the hypothesis is as follows:

H. Springate Score has a significant effect in predicting financial distress.

Zmijewski X-Score Towards Financial Distress. Hadiand Anggraeni (2008), the result of Zmijewski model with the significance of the X-Score shows inaccurate. For that reason, it cannot be used to predict the delisting. The coefficient of determination has value which is very low that is at only $1.4 \%$. This value indicates the ability of the model to explain the delisting Zmijewski, while the other of $88.6 \%$ is explained by the variables which are not included in the equation. Abadi (2017), his research showed that the result of financial ratio calculation calculated using zmijewski x-score between research period 2013-2014, none of the samples examined are bankrupt potential. Therefore, it can be concluded that there are none property sector companies potential towards bankruptcy with the zmijewski $\mathrm{x}$-score model of analysis. Husein (2014), his research showed that Altman, Zmijewski, Springate, and Grover model can be used to predict financial crisis. However, Zmijewski model is the best to predict financial crisis due to highest significance level compared to the other models. Zmijewski model is used for cases emphasizing leverage ratio as financial crisis indicator. Pambekti et al. (2014) concluded that zmijewski model is the best financial distress 
prediction model to predict corporate financial distress in the future. Based on the explanation, the hypothesis is as follows:

H. Zmijewski X-Score has a significant effect in predicting financial distress.

\section{RESEARCH METHOD}

Data. There are two variables in this research:

1. Dependent variable. Dependent variable in this research is financial distress.

2. Independent variable. Independent variable in this research is altman, grover score, springate, and zmijewski model.

Sample. This type of research uses quantitative approach, with a goal to investigaate certain population or sample. Data used in this research is secondary data in the form of financial report in consumer goods company which consecutively listed in Indonesia Stock Exchange year 2013-2017. The population of this research is all consumer goods company listed in Indonesia Stock Exchange year 2013 - 2017. Sample in this research is obtained using purposive sampling on consumer goods company year 2013-2017 as follows:

Table 1. Purposive Sampling

\begin{tabular}{|c|c|c|}
\hline No & Criteria & Amount \\
\hline 1. & $\begin{array}{l}\text { Consumer goods company listed in Indonesia Stock Exchange between } 2013 \\
-2017\end{array}$ & 42 \\
\hline 2. & $\begin{array}{l}\text { Consumer goods company not publishing financial report consecutively } \\
\text { between } 2013-2017\end{array}$ & (8) \\
\hline 3. & Consumer goods company not having positive revenue between $2013-2017$ & $(10)$ \\
\hline & Total sample & 24 \\
\hline
\end{tabular}

This research uses financial distress as dependent variable, and independent variable consisting of altman score, grover score, springate score, and zmijewski score. Testing in this research uses logistic regression analysis, which views the effect of altman score, grover score, springate score, and zmijewski score towards financial distress. This research uses quantitative descriptive approach because the data in this research are numbers in the corporate fiancial report. The goal of descriptive research is to provide researchers history or to illustrate aspects relevant with attention phenomena of the perspective of someone, organization, industry or others which then assists researchers to provide ideas for further researches.

Method of analysis. The method of analysis used in this research is descriptive analysis. Descriptive research isa method that aims to describe a state of the company systematically, actual and accurate by collecting data based on data that appear in the company or organization, where the facts are collected, processed and analyzed so that further can be taken a Calculation and analysis results of altman score, grover score, springate score, and zmijewski score all consumer goods company listed in Indonesia Stock Exchange year $2013-2017$.

\section{RESULTS AND DISCUSSION}

\subsection{Results}

Calculation of Altman Score. Calculation and analysis results of Altman Z-Score of several samples in consumer goods company listed in Indonesia Stock Exchange year 2013 until 2017. 
Table 2. Calculation and Analysis Results of Altman Score method Year 2013

\begin{tabular}{lccccccc}
\hline \multicolumn{1}{c}{ Company Name } & $\mathbf{1 . 2} * \mathbf{X}_{\mathbf{1}}$ & $\mathbf{1 . 4} * \mathbf{X}_{\mathbf{2}}$ & $\mathbf{3 . 3} * \mathbf{X}_{\mathbf{3}}$ & $\mathbf{0 . 6} * \mathbf{X}_{\mathbf{4}}$ & $\mathbf{0 . 9 9 9} * \mathbf{X}_{\mathbf{5}}$ & $\mathbf{Z}$ Score & Information \\
\hline PT. Kalbe Farma,Tbk & 0.5148 & 0.938 & 0.726 & 1.806 & 1.4086 & 5.39 & Healthy \\
PT. Mayora Indah,Tbk & 0.4692 & 0.49 & 0.429 & 0.408 & 1.2288 & 3.02 & Healthy \\
PT. Merek,Tbk & 0.7572 & 0.938 & 1.089 & 1.662 & 1.7083 & 6.15 & Healthy \\
PT. Sekar Bumi,Tbk & 0.162 & 0.21 & 0.495 & 0.402 & 2.5974 & 3.87 & Healthy \\
PT. Pyridam Farma,Tbk & 0.1788 & 0.294 & 0.132 & 0.69 & 1.0889 & 2.38 & GreyArea \\
PT. Siantar Top, Tbk & 0.058 & 0.518 & 0.297 & 0.534 & 1.1489 & 2.57 & GreyArea \\
PT. Sekar Laut,Tbk & 0.1164 & 0.224 & 0.165 & 0.516 & 1.8681 & 2.89 & GreyArea \\
\hline
\end{tabular}

Source : Data processing, 2018

On table 2 above, calculation and analysis results of altman score method year 2013 there are four companies in a healthy state or not bankrupt, which are PT. Kalbe Farma Tbk,PT. Mayora Indah,Tbk ; PT. Merek, Tbk; PT. Sekar Bumi Tbk, where the three companies in grey area (vulnerable to bankruptcy) are PT. Pyridam Farma Tbk; PT. Siantar Top Tbk ; PT. Sekar Laut Tbk. PT Mayora Indah Tbk in 2013 was in a healthy state due to high amount of net working capital and earning before interest and taxes, which indicates the company's ability to manage and fulfill their obligation. PT.Sekar Bumi,Tbk in a healthy state due to high amount of net working capital and earning before interest and taxes, which indicates the three companies' ability to manage and fulfill their obligation. PT. Pyridam Farma,Tbk in 2013 was in the grey area due to low amount of net working capital caused by an increase of short term debt and there was a huge possibility of problems in fulfilling its short term obligation, besides that, the low amount of retained earning undefined by the user would affect the company's net income. This company engages in production and development of drugs (pharmacy) and transaction of medical utililties. This was caused by several factors, including the level of supply and availability of commodity or raw materials, product consumption level, the development of global economy and rupiah's depreciation towards foreign currency. The increase of commodity/raw materials prices and depreciation of rupiah towards foreign currency would negatively affect the company's financial position. PT. Siantar Top,Tbk in 2013 - 2014 was in the grey area due to low amount of net working capital caused by an increase of short term debt and there was a huge possibility of problems in fulfilling its short term obligation, besides that, the low amount of retained earning undefined by the user would affect the company's net income. Siantar Top mainly engages in snacks industry, such as noodle (noodle snacks, namely Soba, Spix Mie Goreng, Mie Gemes, Boyki, Tamiku, Wilco, Fajar, and others), crackers, such as French Fries 2000, Twistko, Leanet, Opotato, and others, biscuits and wafers (Goriorio, Gopotato, Go Malkist, Brio Gopotato, Go Choco Star, Wafer Stick, Superman, Goriorio Magic, Goriorio Otamtam, and others), and candies with various flavors such as DR. Milk, Gaul, Mango, Era Cool, and others. Besides that, PT.Siantar Top, Tbk also has a printing company through a subsidiary (PT Siantar Megah Jaya).

Table 3. Calculation and Analysis Results of Altman Score method Year 2014

\begin{tabular}{lccccccc}
\hline \multicolumn{1}{c}{ Company Name } & $\mathbf{1 . 2} * \mathbf{X}_{\mathbf{1}}$ & $\mathbf{1 . 4} * \mathbf{X}_{\mathbf{2}}$ & $\mathbf{3 . 3} * \mathbf{X}_{\mathbf{3}}$ & $\mathbf{0 . 6}^{*} \mathbf{X}_{\mathbf{4}}$ & $\mathbf{0 . 9 9 9} * \mathbf{X}_{\mathbf{5}}$ & $\mathbf{Z}$ Score & Information \\
\hline PT. Kalbe Farma,Tbk & 0.5532 & 0.994 & 0.726 & 2.184 & 1.38861 & 5.85 & Healthy \\
PT. Mayora Indah,Tbk & 0.3948 & 0.476 & 0.165 & 0.39 & 1.36863 & 2.79 & Grey Area \\
PT. Merek,Tbk & 0.7848 & 0.98 & 0.924 & 1.956 & 1.20879 & 5.85 & Healthy \\
PT. Sekar Bumi,Tbk & 0.2244 & 0.28 & 0.528 & 0.534 & 2.25774 & 3.82 & Healthy \\
PT. Pyridam Farma,Tbk & 0.2088 & 0.336 & 0.066 & 0.768 & 1.27872 & 2.66 & Grey Area \\
PT. Siantar Top, Tbk & 0.1836 & 0.546 & 0.297 & 0.552 & 1.26873 & 2.85 & Grey Area \\
PT. Sekar Laut,Tbk & 0.0924 & 0.182 & 0.231 & 0.408 & 2.01798 & 3.82 & Healthy \\
\hline
\end{tabular}

Source : Data processing, 2019 
On table 3 above, calculation and analysis results of altman score method year 2014 there are four companies in a healthy state or not bankrupt, which are PT.Kalbe Farma,Tbk; PT.Merek,Tbk; and PT.Sekar Bumi,Tbk in a healthy state due to high amount of net working capital and earning before interest and taxes, which indicates the three companies' ability to manage and fulfill their obligation. Where the three companies in grey area (vulnerable to bankruptcy) are PT. Mayora Indah, Tbk; PT.Pyridam Farma Tbk; PT. Siantar Top,Tbk. PT. Mayora Indah, Tbk in 2014 the company was indicated in the grey area due to low market value and high amount of total debt which is the obligation of the company facing its short and long term issues. PT. Pyridam Farma Tbk (PYFA) in 2013 - 2014 was in the grey area due to low amount of net working capital caused by an increase of short term debt and there was a huge possibility of problems in fulfilling its short term obligation, besides that, the low amount of retained earning undefined by the user would affect the company's net income. This company engages in production and development of drugs (pharmacy) and transaction of medical utililties. This was caused by several factors, including the level of supply and availability of commodity or raw materials, product consumption level, the development of global economy and rupiah's depreciation towards foreign currency. The increase of commodity/raw materials prices and depreciation of rupiah towards foreign currency would negatively affect the company's financial position. PT. Siantar Top,Tbk in 2014 was in the grey area due to low amount of net working capital caused by an increase of short term debt and there was a huge possibility of problems in fulfilling its short term obligation, besides that, the low amount of retained earning undefined by the user would affect the company's net income. Siantar Top mainly engages in snacks industry, such as noodle (noodle snacks, namely Soba, Spix Mie Goreng, Mie Gemes, Boyki, Tamiku, Wilco, Fajar, and others), crackers, such as French Fries 2000, Twistko, Leanet, Opotato, and others, biscuits and wafers (Goriorio, Gopotato, Go Malkist, Brio Gopotato, Go Choco Star, Wafer Stick, Superman, Goriorio Magic, Goriorio Otamtam, and others), and candies with various flavors such as DR. Milk, Gaul, Mango, Era Cool, and others.

Table 4. Calculation and Analysis Results of Altman Score method Year 2015

\begin{tabular}{lccccccc}
\hline \multicolumn{1}{c}{ Company Name } & $\mathbf{1 . 2} * \mathbf{X}_{\mathbf{1}}$ & $\mathbf{1 . 4} * \mathbf{X}_{\mathbf{2}}$ & $\mathbf{3 . 3} * \mathbf{X}_{\mathbf{3}}$ & $\mathbf{0 . 6} * \mathbf{X}_{\mathbf{4}}$ & $\mathbf{0 . 9 9 9} * \mathbf{X}_{\mathbf{5}}$ & $\mathbf{Z}$ Score & Information \\
\hline PT. Kalbe Farma,Tbk & 0.5592 & 1.022 & 0.6534 & 13.0845 & 1.2987 & 16.62 & Healthy \\
PT. Mayora Indah,Tbk & 0.4548 & 0.5712 & 0.4752 & 2.7852 & 1.2987 & 5.59 & Healthy \\
PT. Merek,Tbk & 0.6564 & 0.945 & 0.9966 & 9.2928 & 1.52847 & 13.42 & Healthy \\
PT. Sekar Bumi,Tbk & 0.0672 & 0.2968 & 0.231 & 2.6994 & 1.77822 & 5.07 & Healthy \\
PT. Pyridam Farma,Tbk & 0.2712 & 0.399 & 0.0924 & 5.6859 & 1.35864 & 7.81 & Healthy \\
PT. Siantar Top, Tbk & 0.2004 & 0.6244 & 0.396 & 3.6531 & 1.31868 & 6.19 & Healthy \\
PT. Sekar Laut,Tbk & 0.0972 & 0.2282 & 0.2376 & 2.2275 & 1.96803 & 4.76 & Healthy \\
\hline
\end{tabular}

Source : Data processing, 2019

On table 4 above, calculation and analysis results of altman score method year 2015 there are not companies bankrupt (healthy). PT.Kalbe Farma, Tbk; PT. Mayora Indah, Tbk ; PT.Merek, Tbk; PT. Sekar Bumi, Tbk; PT. Pyridam Farma, Tbk; PT.Siantar Top, Tbk; PT. Sekar Laut, Tbk was able to fix the condition and be in a healthy/ not bankrupt state. All the company was able to fix the condition and be in a healthy/ not bankrupt state. This was due to the company's high amount of capital able to repair their management and obligation fulfillment. 
Table 5. Calculation and Analysis Results of Altman Score method Year 2016

\begin{tabular}{lcccccrcc}
\hline \multicolumn{1}{c}{ Company Name } & $\mathbf{1 . 2} * \mathbf{X}_{\mathbf{1}}$ & $\mathbf{1 . 4} * \mathbf{X}_{\mathbf{2}}$ & $\mathbf{3 . 3} * \mathbf{X}_{\mathbf{3}}$ & $\mathbf{0 . 6} * \mathbf{X}_{\mathbf{4}}$ & $\mathbf{0 . 9 9 9} * \mathbf{X}_{\mathbf{5}}$ & $\mathbf{Z}$ Score & Information \\
\hline PT. Kalbe Farma,Tbk & 0.5712 & 1.036 & 0.66 & 14.883 & 1.26873 & 18.42 & Healthy \\
PT. Mayora Indah,Tbk & 0.45 & 0.602 & 0.462 & 3.003 & 1.41858 & 5.94 & Healthy \\
PT. Merek,Tbk & 0.6252 & 1.008 & 0.924 & 11.913 & 1.38861 & 15.86 & Healthy \\
PT. Sekar Bumi,Tbk & 0.06 & 0.252 & 0.099 & 1.914 & 1.48851 & 3.81 & Healthy \\
PT. Pyridam Farma,Tbk & 0.324 & 0.406 & 0.132 & 5.643 & 1.28871 & 7.79 & Healthy \\
PT. Siantar Top, Tbk & 0.186 & 0.616 & 0.297 & 3.267 & 1.11888 & 5.48 & Healthy \\
PT. Sekar Laut,Tbk & 0.1116 & 0.182 & 0.132 & 3.564 & 1.45854 & 5.45 & Healthy \\
\hline
\end{tabular}

Source : Data processing, 2019

On table 5 above, calculation and analysis results of altman score method year 2016 there are not companies bankrupt (healthy). PT.Kalbe Farma, Tbk; PT. Mayora Indah, Tbk ; PT.Merek, Tbk; PT. Sekar Bumi, Tbk; PT. Pyridam Farma, Tbk; PT.Siantar Top, Tbk; PT. Sekar Laut, Tbk was able to fix the condition and be in a healthy/ not bankrupt state. All the company was able to fix the condition and be in a healthy/ not bankrupt state. This was due to the company's high amount of capital able to repair their management and obligation fulfillment.

Table 6. Calculation and Analysis Results of Altman Score method Year 2017

\begin{tabular}{lcccccrcc}
\hline \multicolumn{1}{c}{ Company Name } & $\mathbf{1 . 2} * \mathbf{X}_{\mathbf{1}}$ & $\mathbf{1 . 4}^{*} \mathbf{X}_{\mathbf{2}}$ & $\mathbf{3 . 3}^{*} \mathbf{X}_{\mathbf{3}}$ & $\mathbf{0 . 6}^{*} \mathbf{X}_{\mathbf{4}}$ & $\mathbf{0 . 9 9 9} * \mathbf{X}_{\mathbf{5}}$ & $\mathbf{Z}$ Score & Information \\
\hline PT. Kalbe Farma,Tbk & 0.564 & 1.064 & 0.627 & 16.83 & 1.209 & 20.29 & Healthy \\
PT. Mayora Indah,Tbk & 0.498 & 0.63 & 0.462 & 3.201 & 1.389 & 6.18 & Healthy \\
PT. Merek,Tbk & 0.5448 & 0.938 & 0.792 & 8.745 & 1.359 & 12.38 & Healthy \\
PT. Sekar Bumi,Tbk & 0.24 & 0.182 & 0.033 & 5.61 & 1.129 & 7.19 & Healthy \\
PT. Pyridam Farma,Tbk & 0.4212 & 0.462 & 0.198 & 7.062 & 1.389 & 9.53 & Healthy \\
PT. Siantar Top, Tbk & 0.3012 & 0.742 & 0.396 & 4.752 & 1.199 & 7.39 & Healthy \\
PT. Sekar Laut,Tbk & 0.1044 & 0.182 & 0.132 & 3.069 & 1.429 & 4.92 & Healthy \\
\hline
\end{tabular}

Source : Data processing, 2019

On table 6 above, calculation and analysis results of altman score method year 2016 there are not companies bankrupt (healthy). PT.Kalbe Farma, Tbk; PT. Mayora Indah, Tbk ; PT.Merek, Tbk; PT. Sekar Bumi, Tbk; PT. Pyridam Farma, Tbk; PT.Siantar Top, Tbk; PT. Sekar Laut, Tbk was able to fix the condition and be in a healthy/ not bankrupt state. All the company was able to fix the condition and be in a healthy/ not bankrupt state. This was due to the company's high amount of capital able to repair their management and obligation fulfillment.

Calculation of Grover Score. The result and calculation of Grover Score method, several samples in consumer goods company listed in Indonesia Stock Exchange year 2013 until 2017.

Table 7. Calculation and Analysis Results of Grover Score method on Variable $\mathrm{X}_{1}$

\begin{tabular}{|c|c|c|c|c|c|c|c|}
\hline \multirow{2}{*}{ Company Name } & \multicolumn{5}{|c|}{ Year } & \multirow{2}{*}{ G - Score } & \multirow{2}{*}{ Information } \\
\hline & 2013 & 2014 & 2015 & 2016 & 2017 & & \\
\hline PT. Kalbe Farma,Tbk & 0.707 & 0.76 & 0.768 & 0.785 & 0.775 & 3.795 & Not Bankrupt \\
\hline PT. Mayora Indah, Tbk & 0.645 & 0.542 & 0.625 & 0.618 & 0.684 & 3.114 & Not Bankrupt \\
\hline PT. Merek, Tbk & 1.041 & 1.079 & 0.902 & 0.859 & 0.749 & 4.63 & Not Bankrupt \\
\hline PT. Sekar Laut, Tbk & 0.16 & 0.127 & 0.133 & 0.153 & 0.143 & 0.716 & Not Bankrupt \\
\hline PT. Sekar Bumi, Tbk & 0.222 & 0.308 & 0.092 & 0.082 & 0.33 & 1.034 & Not Bankrupt \\
\hline PT. Unilever Indonesia,Tbk & -0.315 & -0.29 & -0.366 & -0.422 & -0.399 & -1.792 & Bankrupt \\
\hline PT. Multi Bintang Indonesia Tbk & -0.014 & -0.57 & -0.396 & -0.306 & -0.148 & -1.434 & Bankrupt \\
\hline
\end{tabular}


On table 7 above, calculation and analysis results of grover score on variable $\mathrm{X}_{1}$ which is Working capital/Total assets, can be seen that there are five companies not experiencing financial distress which consist of PT.Kalbe Farma, Tbk ; PT. Mayora Indah, Tbk ; PT.Merek, Tbk ; PT.Sekar Laut, Tbk ; PT. Sekar Bumi, Tbk. The higher this ratio, the more the company would be avoided from financial distress. In contrast, there were two companies experiencing financial distress which consist of PT.Unilever, Tbk; PT. Multi Bintang Indonesia, Tbk.

Table 8. Calculation and Analysis Results of Grover Score method on Variable $\mathrm{X}_{2}$

\begin{tabular}{|c|c|c|c|c|c|c|c|}
\hline \multirow{2}{*}{ Company Name } & \multicolumn{5}{|c|}{ Year } & \multirow{2}{*}{ G-Score } & \multirow{2}{*}{ Information } \\
\hline & 2013 & 2014 & 2015 & 2016 & 2017 & & \\
\hline PT. Kalbe Farma,Tbk & 0.748 & 0.748 & 0.673 & 0.691 & 0.663 & 3.523 & Not Bankrupt \\
\hline PT. Mayora Indah, Tbk & 0.442 & 0.17 & 0.49 & 0.483 & 0.496 & 2.081 & Not Bankrupt \\
\hline PT. Merek, Tbk & 1.123 & 0.953 & 1.028 & 0.98 & 0.823 & 4.907 & Not Bankrupt \\
\hline PT. Sekar Laut, Tbk & 0.17 & 0.238 & 0.245 & 0.149 & 0.146 & 0.948 & Not Bankrupt \\
\hline PT. Sekar Bumi, Tbk & 0.51 & 0.544 & 0.238 & 0.102 & 0.064 & 1.458 & Not Bankrupt \\
\hline PT. Unilever Indonesia, Tbk & 1.804 & 1.872 & 1.691 & 1.739 & 1.684 & 8.79 & Not Bankrupt \\
\hline PT. Multi Bintang Indonesia Tbk & 2.995 & 1.633 & 1.092 & 1.974 & 2.413 & 10.107 & Not Bankrupt \\
\hline
\end{tabular}

Source : Data processing, 2019

On table 8 above, calculation and analysis results of grover score on variable $\mathrm{X} 2$ which is Net profit before interest and tax/Total assets, it can be seen that all consumer goods companies used as samples not experiencing financial distress, namely PT.Kalbe Farma, Tbk; PT. Mayora Indah, Tbk ; PT.Merek, Tbk ; PT.Sekar Laut, Tbk ; PT. Sekar Bumi, Tbk.; PT.Unilever, Tbk; PT. Multi Bintang Indonesia, Tbk. This ratio shows the assets productivity level in producing revenue before taxes and interests. The higher this ratio, the more the company would be avoided from financial distress.

Table 9. Calculation and Analysis Results of Grover Score method on Variable $\mathrm{X}_{3}$

\begin{tabular}{|c|c|c|c|c|}
\hline \multirow{2}{*}{ Company Name } & \multicolumn{2}{|r|}{ Year } & \multirow{2}{*}{ G-Score } & \multirow{2}{*}{ Information } \\
\hline & $2013 \quad 2014$ & $2015 \quad 2016$ & & \\
\hline$\overline{\text { PT. Kalbe Farma,Tbk }}$ & $-0.0027-0.003$ & $-0.002-0.0024-0.0022$ & -0.0125 & Bankrupt \\
\hline PT. Mayora Indah, Tbk & $-0.0016-0.001$ & $-0.002-0.0016-0.0016$ & -0.0071 & Bankrupt \\
\hline PT. Merek, Tbk & $-0.004-0.004$ & $-0.004-0.0032-0.0029$ & -0.0177 & Bankrupt \\
\hline PT. Sekar Laut, Tbk & $-0.0005-0.001$ & $-0.001-0.0005-0.0005$ & -0.003 & Bankrupt \\
\hline PT. Sekar Bumi, Tbk & $-0.0018-0.002$ & $-0.001-0.0003-0.0002$ & -0.0051 & Bankrupt \\
\hline PT. Unilever Indonesia, Tbk & $-0.0064-0.007$ & $-0.006-0.0056-0.0059$ & -0.0306 & Bankrupt \\
\hline PT. Multi Bintang Indonesia Tbk & $-0.0104-0.006$ & $-0.004-0.0069-0.0083$ & -0.035 & Bankrupt \\
\hline
\end{tabular}

Source : Data processing, 2019

On table 9 above, calculation and analysis results of grover score on variable on variable $\mathrm{X}_{3}$ which is ROA, it can be seen that all consumer goods companies used as samples are experiencing financial distress, which consist of PT.Kalbe Farma, Tbk ; PT. Mayora Indah, Tbk ; PT.Merek, Tbk ; PT.Sekar Laut, Tbk ; PT. Sekar Bumi, Tbk.; PT.Unilever, Tbk; PT. Multi Bintang Indonesia, Tbk. This is due to the companies experiencing loss, therefore $\mathrm{X}_{3}$ calculation results in negative.

Calculation of Springate Score. The result of calculation and analysis of Springate Score method towards several samples of consumer goods company listed in Indonesia Stock Exchange year 2013 until 2017. 
Table 10. Calculation and Analysis Results of Springate Score method on variable $\mathbf{X}_{1}$

\begin{tabular}{lccccccc}
\hline \multirow{1}{*}{ Company Name } & \multicolumn{5}{c}{ Year } & \multirow{2}{*}{ S - Score } & \multirow{2}{*}{ Information } \\
\cline { 2 - 6 } & $\mathbf{2 0 1 3}$ & $\mathbf{2 0 1 4}$ & $\mathbf{2 0 1 5}$ & $\mathbf{2 0 1 6}$ & $\mathbf{2 0 1 7}$ & & \\
\hline PT. Pyridam Farma ,Tbk & 0.15347 & 0.17922 & 0.23278 & 0.2781 & 0.36153 & 1 & Healthy \\
PT. Mandon Indonesia ,Tbk & 0.36668 & 0.21424 & 5.3869 & 0.44908 & 0.4429 & 7 & Healthy \\
PT. Tempo Scan Pacific,Tbk & 0.50264 & 0.45423 & 0.42745 & 0.42642 & 0.42127 & 2 & Healthy \\
PT. Unilever Indonesia, Tbk & -0.19673 & -0.1813 & -0.2287 & -0.2637 & -0.2493 & -1 & Bankrupt \\
PT. Siantar Top,Tbk & 0.05974 & 0.15759 & 0.17201 & 0.15965 & 0.25853 & 1 & Bankrupt \\
PT. Sekar Laut, Tbk & 0.09991 & 0.07931 & 0.08343 & 0.09579 & 0.08961 & 0 & Bankrupt \\
PT. Sekar Bumi, Tbk & 0.13905 & 0.19261 & 0.05768 & 0.0515 & 0.206 & 1 & Bankrupt \\
\hline
\end{tabular}

Source : Data processing, 2019

On table 10 above, calculation and analysis of springate score method on variable $\mathrm{X}_{1}$ which is Working capital/Total assets. The higher this ratio, the more the company would be avoided from financial distress. There were three companies not experiencing financial distress, which consist of PT.Pyridam Farma, Tbk ; PT.Mandon Indonesia,Tbk ; and PT.Tempo Scan Pacific, Tbk. If $Z>0,862$ then the company is categorized as a healthy company, while there were four companies experiencing financial distress, which consist of PT.Siantar Top,Tbk ; PT.Sekar Laut, Tbk ; PT.Sekar Bumi, Tbk. Criteria for the springate model equation is if $\mathrm{Z}<0,862$ then it is categorized as a bankrupt company.

Table 11. Calculation and Analysis Results of Springate Score method on variable $\mathbf{X}_{\mathbf{2}}$

\begin{tabular}{lccccccc}
\hline \multicolumn{1}{c}{ Company Name } & \multicolumn{5}{c}{ Year } & \multirow{2}{*}{ S - Score } & \multirow{2}{*}{ Information } \\
\cline { 2 - 7 } & $\mathbf{2 0 1 3}$ & $\mathbf{2 0 1 4}$ & $\mathbf{2 0 1 5}$ & $\mathbf{2 0 1 6}$ & $\mathbf{2 0 1 7}$ & & \\
\hline PT. Pyridam Farma ,Tbk & 0.123 & 0.061 & 0.08596 & 0.1228 & 0.1842 & 1 & Bankrupt \\
PT. Mandon Indonesia ,Tbk & 0.43 & 0.368 & 0.8596 & 0.307 & 0.307 & 2 & Healthy \\
PT. Tempo Scan Pacific,Tbk & 0.461 & 0.399 & 0.34384 & 0.307 & 0.307 & 2 & Healthy \\
PT. Unilever Indonesia, Tbk & 1.627 & 1.689 & 1.52579 & 1.5657 & 1.5043 & 8 & Healthy \\
PT. Siantar Top,Tbk & 0.276 & 0.276 & 0.3684 & 0.2763 & 0.3684 & 2 & Healthy \\
PT. Sekar Laut, Tbk & 0.154 & 0.215 & 0.22104 & 0.1228 & 0.1228 & 1 & Bankrupt \\
PT. Sekar Bumi, Tbk & 0.461 & 0.491 & 0.2149 & 0.0921 & 0.0307 & 1 & Healthy \\
\hline
\end{tabular}

Source : Data processing, 2019

On table 11 above, calculation and analysis of springate score method on variable $\mathrm{X}_{2}$ which is Net profit before interest and tax/Total assets. There were five companies not experiencing financial distress, namely PT. Mandom Indonesia, Tbk; PT.Tempo Scan Pacific, Tbk ; PT.Unilever Indonesia, Tbk ; PT. Siantar Top, Tbk; and PT. Sekar Bumi,Tbk. If $\mathrm{Z}>0,862$ then the company is considered healthy, while there were two companies experiencing financial distress, namely PT. Pyridam Farma, Tbk and PT.Sekar Laut, Tbk. Criteria for the springate model equation is if $\mathrm{Z}<0,862$ then it is categorized as a bankrupt company. 
Tabel 12. Calculation and Analysis Results of Springate Score method on variable $\mathbf{X}_{3}$

\begin{tabular}{lccccccc}
\hline \multicolumn{1}{c}{ Company Name } & \multicolumn{5}{c}{ Year } & \multirow{2}{*}{ S - Score } & \multirow{2}{*}{ Information } \\
\cline { 2 - 7 } & $\mathbf{2 0 1 3}$ & $\mathbf{2 0 1 4}$ & $\mathbf{2 0 1 5}$ & $\mathbf{2 0 1 6}$ & $\mathbf{2 0 1 7}$ & & \\
\hline PT. Pyridam Farma ,Tbk & 0.112 & 0.053 & 0.08184 & 0.1221 & 0.284 & 1 & Bankrupt \\
PT. Mandon Indonesia ,Tbk & 0.706 & 0.323 & 1.7259 & 0.6626 & 0.614 & 4 & Healthy \\
PT. Tempo Scan Pacific,Tbk & 0.403 & 0.389 & 0.27456 & 0.2864 & 0.244 & 2 & Healthy \\
PT. Unilever Indonesia, Tbk & 0.561 & 0.587 & 0.51018 & 0.5194 & 0.488 & 3 & Healthy \\
PT. Siantar Top,Tbk & 0.152 & 0.205 & 0.27588 & 0.2574 & 0.528 & 1 & Healthy \\
PT. Sekar Laut, Tbk & 0.086 & 0.112 & 0.11352 & 0.0977 & 0.079 & 0 & Bankrupt \\
PT. Sekar Bumi, Tbk & 0.185 & 0.284 & 0.11814 & 0.0429 & 0.04 & 1 & Bankrupt \\
\hline
\end{tabular}

Source : Data processing, 2019

On table 12 above, calculation and analysis of springate score method on variable $\mathrm{X}_{3}$ which is Net before taxes/Current liabilities. This ratio is considered able to reflect more on corporate condition through revenue level, operation expense and debt payment, where the post is very dominant in determining the springate score value. There were four companies not experiencing financial distress, namely PT. Mandom Indonesia, Tbk; PT.Tempo Scan Pacific, Tbk ; PT.Unilever Indonesia, Tbk ; PT. Siantar Top, Tbk. If Z $>0,862$ then the company is considered healthy, while there were three companies experiencing financial distress, namely PT. Pyridam Farma, Tbk; PT.Sekar Laut, Tbk ; and PT.Sekar Bumi, Tbk. Criteria for the springate model equation is if $\mathrm{Z}<0,862$ then it is categorized as a bankrupt company.

Table 13. Calculation and Analysis Results of Springate Score method on variable $\mathbf{X}_{4}$

\begin{tabular}{|c|c|c|c|c|c|c|c|}
\hline \multirow{2}{*}{ Company Name } & \multicolumn{5}{|c|}{ Year } & \multirow{2}{*}{ S - Score } & \multirow{2}{*}{ Information } \\
\hline & 2013 & 2014 & 2015 & 2016 & 2017 & & \\
\hline PT. Pyridam Farma ,Tbk & 0.436 & 0.512 & 0.5444 & 0.516 & 0.556 & 3 & Healthy \\
\hline PT. Mandom Indonesia ,Tbk & 0.552 & 0.492 & 0.4444 & 0.46 & 0.456 & 2 & Healthy \\
\hline PT. Tempo Scan Pacific,Tbk & 0.504 & 0.532 & 0.5204 & 0.552 & 0.512 & 3 & Healthy \\
\hline PT. Unilever Indonesia, Tbk & 0.92 & 0.964 & 0.9276 & 0.956 & 0.868 & 5 & Healthy \\
\hline PT. Siantar Top,Tbk & 0.46 & 0.508 & 0.53 & 0.448 & 0.48 & 2 & Healthy \\
\hline PT. Sekar Laut, Tbk & 0.748 & 0.808 & 0.79 & 0.584 & 0.572 & 4 & Healthy \\
\hline PT. Sekar Bumi, Tbk & 1.04 & 0.904 & 0.7124 & 0.596 & 0.452 & 4 & Healthy \\
\hline
\end{tabular}

Source : Data processing, 2019

On table 13 above, calculation and analysis of springate score method on variable $\mathrm{X}_{4}$ which is Sales/Total assets. Seven companies not experiencing financial distress, namely PT. Pyridam Farma, Tbk; PT. Mandom Indonesia, Tbk; PT.Tempo Scan Pacific, Tbk ; PT.Unilever Indonesia, Tbk ; PT. Siantar Top, Tbk ; PT.Sekar Laut, Tbk ; and PT.Sekar Bumi, Tbk. If $\mathrm{Z}>0,862$ then the company is considered a healthy company.

Calculation of Zmijewski Score. The result of calculation and analysis of zmijewski score method towards several samples of consumer goods company listed in Indonesia Stock Exchange year 2013 until 2017. 
Table 14. Calculation and Analysis Results of Zmijewski Score method on variable $X_{1}$

\begin{tabular}{lccccccc}
\hline \multirow{1}{*}{\multicolumn{1}{c}{ Company Name }} & \multicolumn{5}{c}{ Year } & \multirow{2}{*}{ X Score } & \multirow{2}{*}{ Information } \\
\cline { 2 - 6 } & $\mathbf{2 0 1 3}$ & $\mathbf{2 0 1 4}$ & $\mathbf{2 0 1 5}$ & $\mathbf{2 0 1 6}$ & $\mathbf{2 0 1 7}$ & & \\
\hline PT. Mayora Indah,Tbk & 0.45 & 0.135 & 0.495 & 0.45 & 0.45 & 1.98 & Healthy \\
PT. Merek,Tbk & 1.125 & 1.125 & 0.99 & 0.9 & 0.765 & 4.905 & Healthy \\
PT. Pyridam Farma, Tbk & 0.135 & 0.045 & 0.045 & 0.135 & 0.18 & 0.54 & Healthy \\
PT. Nippon Indosari Corpindo, Tbk & 0.36 & 0.36 & 0.405 & 0.405 & 0.09 & 1.62 & Healthy \\
PT. Siantar Top, Tbk & 0.315 & 0.315 & 0.405 & 0.315 & 0.405 & 1.755 & Healthy \\
PT. Sekar Laut ,Tbk & 0.135 & 0.18 & 0.225 & 0.135 & 0.135 & 0.81 & Healthy \\
PT. Sekar Bumi,Tbk & 0.495 & 0.585 & 0.225 & 0.09 & 0.045 & 1.44 & Healthy \\
\hline
\end{tabular}

Source : Data processing, 2019

On table 14 above, calculation and analysis of zmijewski score on variable $\mathrm{X}_{1}$ which is return on assets from total debt to total assets ratio which affects significantly. Seven companies is not experiencing financial distress, namely PT.Mayora Indah, Tbk; PT.Merek, Tbk; PT. Pyridam Farma, Tbk; PT. Nippon Indosari Corpindo, Tbk; PT.Siantar Top, Tbk; PT. Sekar Laut, Tbk; PT.Sekar Bumi, Tbk.

Table 15. Calculation and Analysis Results of Zmijewski Score method on variable $X_{2}$

\begin{tabular}{lccccccc}
\hline \multirow{2}{*}{\multicolumn{1}{c}{ Company Name }} & \multicolumn{5}{c}{ Year } & \multirow{2}{*}{ X Score } & \multirow{2}{*}{ Information } \\
\cline { 2 - 7 } & $\mathbf{2 0 1 3}$ & $\mathbf{2 0 1 4}$ & $\mathbf{2 0 1 5}$ & $\mathbf{2 0 1 6}$ & $\mathbf{2 0 1 7}$ & & \\
\hline PT. Mayora Indah,Tbk & 3.363 & 3.42 & 3.078 & 3.021 & 2.85 & 15.732 & Healthy \\
PT. Merek,Tbk & 1.482 & 1.311 & 1.482 & 1.2312 & 1.539 & 7.0452 & Healthy \\
PT. Pyridam Farma, Tbk & 2.622 & 2.451 & 2.052 & 2.0976 & 1.767 & 10.9896 & Healthy \\
PT. Nippon Indosari Corpindo, Tbk & 3.192 & 3.135 & 3.192 & 2.8785 & 2.166 & 14.5635 & Healthy \\
PT. Siantar Top, Tbk & 2.964 & 2.964 & 2.679 & 2.85 & 2.28 & 13.737 & Healthy \\
PT. Sekar Laut, Tbk & 3.021 & 3.363 & 3.363 & 2.7246 & 2.907 & 15.3786 & Healthy \\
PT. Sekar Bumi,Tbk & 3.363 & 2.964 & 3.078 & 3.6024 & 2.052 & 15.0594 & Healthy \\
\hline
\end{tabular}

Source : Data processing, 2019

On table 15 above, calculation and analysis of zmijewski score on variable $\mathrm{X}_{2}$ which is debt ratio from net profit after taxes to total assets which affects significantly. Seven companies not experiencing financial distress, namely PT.Mayora Indah, Tbk; PT.Merek, Tbk; PT. Pyridam Farma, Tbk; PT. Nippon Indosari Corpindo, Tbk; PT.Siantar Top, Tbk; PT. Sekar Laut, Tbk; PT.Sekar Bumi, Tbk.

Table 16. Calculation and Analysis Results of Zmijewski Score method on variable $X_{3}$

\begin{tabular}{|c|c|c|c|c|c|c|c|}
\hline \multirow{2}{*}{ Company Name } & \multicolumn{5}{|c|}{ Year } & \multirow[b]{2}{*}{ X Score } & \multirow[b]{2}{*}{ Information } \\
\hline & 2013 & 2014 & 2015 & 2016 & 2017 & & \\
\hline PT. Mayora Indah,Tbk & -0.0098 & -0.0083 & -0.00946 & -0.009 & -0.00952 & -0.04604 & Bankrupt \\
\hline PT. Merek,Tbk & -0.0159 & -0.0183 & -0.014608 & -0.01684 & -0.01232 & -0.077948 & Bankrupt \\
\hline PT. Pyridam Farma, Tbk & -0.0061 & -0.0065 & -0.007964 & -0.00876 & -0.01408 & -0.043424 & Bankrupt \\
\hline PT. Nippon Indosari Corpindo, Tbk & -0.0045 & -0.0054 & -0.008212 & -0.01184 & -0.009 & -0.038972 & Bankrupt \\
\hline PT. Siantar Top, Tbk & -0.0046 & -0.0059 & -0.006312 & -0.0066 & -0.01056 & -0.0 & Bankrupt \\
\hline PT. Sekar Laut ,Tbk & -0.0049 & -0.0047 & -0.004768 & -0.00524 & -0.00504 & -0.024668 & Bankrupt \\
\hline PT. Sekar Bumi,Tbk & -0.005 & -0.0059 & -0.00458 & -0.0044 & -0.00652 & -0.02636 & Bankrupt \\
\hline
\end{tabular}

Source : Data processing, 2019

On table 16 above, calculation and analysis of zmijewski score on variable $\mathrm{X}_{3}$ which is currrent ratio from current assets to current liability which affects significantly. Seven companies experiencing financial distress, namely PT.Mayora Indah, Tbk; PT.Merek, Tbk; PT. Pyridam Farma, Tbk; PT. Nippon Indosari Corpindo, Tbk; PT.Siantar Top, Tbk; PT. 
Sekar Laut, Tbk; PT.Sekar Bumi, Tbk. That all companies experiencing financial distress where current assets to current liabilities do not affect significantly.

\subsection{Discussion}

The effect of Altman Score Towards Financial Distress. Based on the research on several samples of consumer goods company used between 2013-2017 with AltmanZ-Score model using the equation $\mathrm{Z}=1.2 \mathrm{Z}_{1}+1.4 \mathrm{Z}_{2}+3.3 \mathrm{Z}_{3}+0.6 \mathrm{Z}_{4}+0.999 \mathrm{Z}_{5}$, with $\mathrm{Z}<1,8$; then it is considered in a financial distress, while if $Z$ is between 1,81 and 2,99; then it is considered in the grey area (in a critical condition) and if $Z>2,99$ then it is considered healthy. Therefore the results are there were three companies in a healthy condition, namely PT. Kalbe Farma Tbk, PT. Merek Tbk, PT. Sekar Bumi Tbk where the three companies has a fairly good financial condition, however in 2013 and 2014 three companies in the grey area (vulnerable to bankruptcy), namely PT. Pyridam Farma Tbk, PT. Siantar Top Tbk, PT. Sekar Laut Tbk and one company in the grey area in 2014 is PT. Mayora Indah Tbk. Altman Score model can be used to predict financial distress, which means accept $\mathrm{H}_{1}$, this result is consistent with previous researches by Safitra (2013), Kurniawanti (2013), Jefri (2016), Kakauhe and Pontoh (2017) where in this research the three categories, which are healthy, grey area and financial distress are almost in every research by three of them.

The Effect of Grover Score Towards Financial Distress. Based on the research on several samples of consumer goods company used between 2013-2017 with Grover Score model using the equation $\mathrm{G}=1,650 \mathrm{X}_{1}+3,404 \mathrm{X}_{2}-0,016 \mathrm{X}_{3}+0,057$. Grover model categorizes companies in bankruptcy with score less than or equal to - $0,02(Z<-0,02)$. While the score of companies categorized as non-bankrupt is more than or equal to $0,01(\mathrm{Z}>$ $0,01)$. Therefore, the results are in variable $X_{1}$ which is Working capital/Total assets it can be seen that there were five companies not in financial distress and two in financial distress. While in variable $X_{2}$, none of the samples are in financial distress. On variable $X_{3}$, all samples are experiencing financial distress. Grover Score model can be used to predict financial distress, which means accept $\mathrm{H}_{2}$, this result is consistent to previous researches by Pambekti et al (2014), Gunawan et al (2017), Fauzan and Sutiono (2017), and Syamni et.al (2018).

The Effect of Springate Score Towards Financial Distress. Based on the research on several samples of consumer goods company used between 2013-2017 with Springate Score model using the equation $S=1.03 \mathrm{~A}+3.07 \mathrm{~B}+0.66 \mathrm{C}+0.4 \mathrm{D}$. Criteria for the springate model equation is if $\mathrm{Z}<0,862$ then it is considered bankrupt and if $\mathrm{Z}>0,862$ then the company is considered healthy. Therefore the results are in variable $\mathrm{X}_{1}$ which is Working capital/Total assets it can be seen that there were three companies not in financial distress and four in financial distress. While in variable $\mathrm{X}_{2}$, there were five companies not in financial distress and two in financial distress. In variable $X_{3}$, there were four companies not in financial distress and three in financial distress. While in variable $\mathrm{X}_{4}$, all sample companies not experiencing financial distress. Springate Score model can be used to predict financial distress, which means accept $\mathrm{H}_{3}$, the result is consistent with previous researches by Topowijono (2015), Meiliawati (2016), and Abadi (2017).

The Effect of Zmijewski Score Towards Financial Distress. Based on the research on several samples of consumer goods company used between 2013-2017 with Zmijewski Score model using the equation $X=-4,3-4,5 X_{1}+5,7 X_{2}-0,004 X_{3}$. Criteria for the zmijewski model is the company is considered in distress if the probability is more than 0 . In another words, the value of $\mathrm{X}$ is 0 . Therefore, the cut-off value applicable in this model is 0 . This means, companies with $\mathrm{X}$ value more than or equal to 0 are predicted to experience financial distress in the future. In contrast, companies with $\mathrm{X}$ value less than 0 are predicted not to experience financial distress. Therefore obtained in variable $\mathrm{X}_{1}$ which is return on 
assets. All companies would not experience financial distress. While in variable $\mathrm{X}_{2}$ which is debt ratio. All companies also would not experience financial distress and in variable $\mathrm{X}_{3}$ which is current ratio experience the opposite of variable $X_{1}$ and $X_{2}$ where all experience financial distress. Zmijewski Score model can be used to predict financial distress, which means accept $\mathrm{H}_{4}$, the result is consistent with previous researches by Anggraeni and Hadi (2008), Husein (2014), Pambekti et al. (2014), and inconsistent with research by Abadi (2017).

\section{CONCLUSION}

Based on the results obtained by data analysis, it can be concluded that Altman model can be used to predict financial distress, Grover model can be used to predict financial distress, Springate model can be used to predict financial distress, Zmijewski model can be used to predict financial distress. In this research, there were several limitations which may affect research results, namely variable used to detect financial distress and it is recommended to add another model to be able to detect financial distress, for example, beneish score and other models such as Ohlson, and for the next studies, broadening samples including financial report of other companies can be conducted in order to prove which model could detect financial distress.

\section{REFERENCES}

Altman, E. I. (1968). Financial Ratios, Discriminant Analysis and the Prediction of Corporate Bankruptcy. The Journal of Finance. Vol 23 No 4.

Aziz, M. Adnan \& Humayon A. Dar. (2006). Predicting Corporate Bankcruptcy: Where We Stand ?. The international journal of business in society, Vol. 6 Iss 1 pp. $18-33$

Aghajani, V., \& Jouzbarkand, M. (2012). The Creation Of Bankruptcy Prediction Model Using Springate and SAF Models. International Proceedings of Economics Development and Research. Vol 54 No 2. DOI: 10.7763/IPEDR.

Abadi, Muhammad Taufiq \& Nunung Ghoniyah. (2016). Studi Potensi Kebangkrutan pada Perusahaan Industri Properti yang Go Public di Bursa Efek Indonesia. Jurnal Riset Bisnis Indonesia, Vol. 13 No. 1 Januari 2016, Hal 91 - 100.

Brimantyo.,Topowijono., \& Husaini, A.S. (2012).Penerapan Analisis Altman Z Score Sebagai Salah Satu Alat Untuk Mengetahui Potensi Kebangkrutan Perusahaan Pada perusahaan Telekomunikasi Yang Listing di BEI Periode Tahun 2009-2011”. Jurnal Administrasi Bisnis. Vol 1 No 1.

Ben, Ditiro Alam. et.al. (2015).Analisis Metode Springate (S Score) Sebagai Alat untuk Memprediksi Kebangkrutan Perusahaan (Studi pada Perusahaan Property \& Real Estate yang listing di Bursa Efek Indonesia pada tahun 2011 - 2013). Jurnal Administrasi Bisnis (JAB). Vol. 21. No.1. April.

Diakomihalis, M. N. (2012). The Accuracy of Altman's Models in Predicting Hotel Bankruptcy. International Journal of Accounting and Financial Reporting. Vol 2 No 2.

Edy \& May Tania. (2018). Ketepatan Model Altman, Springate, Zmijewski \& Grover dalam Memprediksi Financial Distress. Jurnal Reviu Akuntansi dan Keuangan.

Fahmi, I. (2013). Analisis Laporan Keuangan. Bandung: Alfabeta.

Fauzan, Hafiz \& Fidya Sutiono. (2017). Perbandingan Model Altman Z-Score, Zmijewski, Springate,dan Grover dalam Memprediksi Kebangkrutan Perusahaan Perbankan (Studi Kasus Pada BEI Tahun 2011 - 2015). Jurnal Online Insan Akuntan, Vol.2, No.1, Juni 2017, 49-60. 
Grover, J., \& Lavin, A. (2001). Financial Ratios, Discriminant Analysis and The Prediction of Corporate Bankruptcy: a Service Industry Extension of Altman's Z-Score Model of Bankruptcy Prediction. Working Paper. Southern Finance Assosiation Annual Meeting.

Gunawan, Barbara.et.al.(2017). Perbandingan Prediksi Financial Distress dengan Model Altman, Grover \& Zmijewski. Jurnal Akuntansi dan Investasi. Vol. 18. No.1.

(https://www.investopedia.com/terms/a/altman.asp).

Hadi, Syamsul, and Atika Anggraeni.(2008).Pemilihan Prediktor Delisting Terbaik (Perbandingan antara The Zmijewski Model, The Altman Model, dan The Springate Model', Jurnal Akuntansi dan Auditing Indonesia, Vol. 12, No. 2, pp.1-9.

Husein, M.Fakhri and Galuh Tri Pambekti. (2014). Precision of the models of Altman, Springate, Zmijewski, and Grover for predicting the financial distress. Journal of Economics, Business, and Accountancy Ventura Vol. 17, No. 3, December 2014, pages $405-416$.

Jefri, (2016), Analisis Prediksi Kebangkrutan menggunakan model Altman Z-Score pada perusahaan makanan dan minuman di Bursa Efek Indonesia 2012-2014, 1 November 2016.

Kurniawanti, (2013), Analisis Penggunaan Altman Z-Score untuk Memprediksi Potensi Kebangkrutan Pada Perusahaan Makanan dan Minuman yang terdaftar di Bursa Efek Indonesia periode 2007-2011, 1 November 2016.

Kakauhe, Anastasya Claudio \& Winston Pontoh. (2017). Analisis Model Altman (Z-Score) dalam mengukur kinerja Keuangan untuk Memprediksi Kebangkrutan pada Perusahaan Manufaktur Sektor Industri Barang Konsumsi di Bursa Efek Indonesia (BEI) periode 2010-2014. Jurnal Accountability. Vol.06, Nomor 01. 18 - 27.

Meita, E. (2015). Analisis Penggunaan Metode Altman, Springate, dan Zmijewski dalam Memprediksi Kebangkrutan Perusahaan Pertambangan Batubara. Jurnal Mahasiswa UNESA.

Meiliawati, Anggi \& Isharijadi. (2016). Analisis Perbandingan Model Springate dan Altman Z Score Terhadap Potensi Financial Distress (Studi Kasus Pada Perusahaan Sektor Kosmetik Yang Terdaftar Di Bursa Efek Indonesia). Jurnal Akuntansi dan Pendidikan, Volume 5, Nomor 1, April 2016.

Prihadi,Toto. (2010). Analisis Laporan Keuangan. Penerbit PPM Manajemen: Jakarta

Prihathini N. \& Ratna Sari. (2013). Prediksi kebangkrutan dengan model Grover, Altman, Z Score, Springate dan Zwijewski pada perusahaan Food and Beverage di Bursa Efek Indonesia. E Jurnal Akuntansi Universitas Udayana. ISSN 2302-8556.

Pambekti, G. T.et.al. (2014). Analisis Ketepatan Model Altman, Springate, Zmijewski, dan Grover untuk Prediksi Financial distress (Studi Pada Perusahaan Yang Masuk Dalam Daftar Efek Syariah Tahun 2009-2012). Disertasi Doktoral, Universitas Islam Negeri Sunan Kalijaga.

Prabowo, Reza \& Wibowo. (2015). Analisis Perbandingan Model Altman Z-Score, Zmijewski, dan Springate dalam Memprediksi Kebangkrutan Perusahaan Delisting di BEI Periode 2008 - 2013. Account, Jurnal Akuntansi, Keuangan dan Perbankan. Volume 1 No.3. Tahun 2015. Politeknik Negeri Jakarta.

Rhomadhona, M. N. (2014). Analisis Perbandingan Kebangkrutan Model Altman, Model Springate, dan Model Zmijewski Pada Perusahaan yang Tergabung dalam Grup Bakrie yang Terdaftar di Bursa Efek Indonesia Periode 2010-2012. Jurnal Universitas Negeri Surabaya.

Sari, Enny Wahyu Puspita. (2014). Penggunaan model Zmijewski, Springate, Altman Z- Score dan Grover dalam memprediksi kepailitan pada Perusahaan transportasi yang 
terdaftar di Bursa Efek Indonesia. Jurnal Mahasiswa. Universitas Dian Nuswantoro. Semarang.

Safitra, Batara Aldino. et.al(2013). Analisis Metode Altman (Z Score) sebagai Alat Evaluasi Guna Memprediksi Kebangkrutan Perusahaan (Studi pada Industri Rokok yang Terdaftar di BEI Periode 2007 - 2011). Jurnal Mahasiswa. Universitas Brawijaya.

Syamni, Ghazali.et.al.(2018). Bankruptcy Prediction Models and Stock Prices of the Coal Mining Industry in Indonesia. Etikonomi.Volume 17 (1), $2018: 57$ - 68.

Springate, G. L. (1978). Predicting the Possibility of Failure in a Canadian firm. (Unpublished Thesis). Britisch Columbia, Canada: Simon Fraser University.

Rini, Triastuti (2015). Analisis Komparasi Model Prediksi Financial Distress Altman, Springate, Grover dan Ohlson Pada Perusahaan Manufaktur yang Terdaftar di Bursa Efek Indonesia Jurnal Ekonomi Vol XX No 3.

Zmijewski, M. E. (1984). "Methodological Issues Relate to the Estimation of Financial of Financial Distress Prediction Models". Journal of Accounting Research.Vol 2. 